\title{
In vitro Gynogenic Plant Production in Allium tuncelianum (Kollman) Özhatay, Matthew \& Şiraneci
}

\section{Fevziye Celebi-Toprak}

Pamukkale Üniversitesi: Pamukkale Universitesi

\section{Zeynep Ergun}

Pamukkale University: Pamukkale Universitesi

\author{
Ali R. Alan ( $\square$ aalan2@gmail.com ) \\ Pamukkale University https://orcid.org/0000-0002-8175-4669
}

\section{Research Article}

Keywords: Allium tuncelianum, flow cytometry, gynogenesis, haploid, in vitro

Posted Date: September 21st, 2021

DOI: https://doi.org/10.21203/rs.3.rs-893428/v1

License: (a) (i) This work is licensed under a Creative Commons Attribution 4.0 International License. Read Full License 


\section{Abstract}

Allium tuncelianum (Kollman) Özhatay, Matthew \& Şiraneci forms a single-cloved edible white bulb with mild garlic (A. sativum) odour and taste. Its ability to form seeds make it suitable for genetic improvement via classical and modern approaches. A detailed study was carried out to determine the gynogenesis potential of two A. tuncelianum (AT1 and AT2) accessions. Unopened flower buds of A. tuncelianum accessions were cultured in various BDS- and MS-based induction media. A total of $17(0.09 \%)$ gynogenic plantlets were obtained from 20000 flower buds used in gynogenesis induction experiment. Accessions showed slight differences in their responses to gynogenesis induction cultures. The highest gynogenic plantlet production frequency $(0.34 \%)$ in AT1 was achieved flower buds cultured in T12 medium (MS with $100 \mathrm{~g} / \mathrm{L}$ sucrose, $1 \mathrm{mg} / \mathrm{L}$ a-naphthalene acetic acid (NAA) and $8 \mathrm{mg} / \mathrm{L}$ isopentenyl adenine (2IP). Flower buds of AT2 showed the highest gynogenic plantlet production response $(0.44 \%)$ in T2 medium (BDS with $50 \mathrm{~g} / \mathrm{L}$ sucrose). Eight of 17 gynogenic plantlets continued to grow and became healthy plants with green leaves and well established roots. Flow cytometric (FCM) analysis of well-developed gynogenic plants showed that two were haploid ( $25 \%$ ), four were diploid (50\%), and two were mixoploid (25\%) for haploid and diploid cells. Nine gynogenic plantlets showing abnormal development were diploid. Therefore, formation of gynogenic plantlets with abnormal phenotypes was likely due to genetic factors. Results obtained from this study suggest use of DH technology in the production of homozygous A. tuncelianum inbreeds in variety improvement programs.

\section{Introduction}

Allium tuncelianum (Kollman) Özhatay, Matthew \& Şiraneci is an edible Allium species endemic to Tunceli province located in mountainous Eastern Turkey (Özhatay 2002). This plant forms single cloved white bulbs that are peeled easily and taste like mild garlic (A. sativum). It is not a domesticated plant species. In the areas where it grows naturally, leaves and bulbs of $A$. tuncelianum are collected and consumed like garlic. Uncontrolled collection from nature in high quantities leads to severe genetic erosion and put this species at a risk of extinction. A. tuncelianum is considered as a vulnerable threatened plant species (Etoh and Simon 2002; Ipek et al. 2008; Kizil et al. 2012).

This species is suitable for cultivation under field conditions by planting bulbs gathered from nature (Kizil and Khawar 2017). However, there is no record of any breeding program aiming to develop new varieties of this species with desired agronomical traits. In many crop species, development of homozygous plants (inbred lines) takes many generations through conventional selfing technique. Like other Allium species, $A$. tuncelianum is highly heterozygous and may show strong inbreeding depression during the development of inbred lines. Bringing this species under cultivation can eliminate the collection practice and help saving wild populations in nature. Development of new lines of this wild edible species suited for cultivation is not an easy task. Attempts to develop new A. tuncelianum lines though classical breeding may be hindered due to factors such as low adaptability to field conditions, high levels of heterozygosity, tendency towards outbreeding, and severe inbreeding depression. It is highly likely that the desired traits of $A$. tuncelianum are controlled by complex traits as in other Allium species. It is expected that the process of developing genetically uniform $A$. tuncelianum lines through conventional breeding approaches will take a long time. 
Breeders can try shortening pure line development by utilizing doubled haploid (DH) techniques allowing production of fully homozygous lines in one generation.

According to Dunwell (2010), applicability of DH techniques was tested in several hundred plant species. However, utilization of these techniques in plant breeding programs is still not wide spread as hoped. One of the problems hindering the wide spread utilization of $\mathrm{DH}$ techniques is that responses of male (microspore) and female (ovule) gametes to induction procedures are governed by the genotype of the donor plants. Further, induction of haploid regeneration is limited to certain techniques in some species. Attempts of androgenesis induction in various Allium species and their interspecific hybrids were not successful (Keller and Korzun 1996). Therefore, Allium species are likely recalcitrant to androgenesis induction. Gynogenesisbased gametic embriyogenesis technique was used to induce haploidization in several economically important Alliums including onion (Muren 1989; Campion and Alloni 1990; Keller 1990; Bohanec and Jakse 1999; Alan et al. 2004; Alan 2021; Kaska et al. 2020a), interspecific hybrids of onion and A. roylei (Alan et al. 2003), shallot (Sulistyaningsih et al. 2002), leek (Alan et al. 2016; Celebi-Toprak and Alan 2021), and Chinese chive (Kojima and Kawaguchi 1989). Kaska et al. (2020b) reported production of three stunted gynogenic plantlets from $A$. tuncelianum and suggested continuation of gynogenesis induction studies to improve the applicability of this technique in order to obtain healthy haploid and DH plants. There is a wellestablished DH plant development method for $A$. cepa (onion), which is successfully incorporated into improvement programs of this species (Alan 2021; Hyde et al. 2012). The gynogenesis technique can be adopted to produce haploid and $\mathrm{DH}$ plants of $A$. tuncelianum.

When applied successfully, gynogenesis-based DH technique can be used in the production of homozygous A. tuncelianum lines in one generation. In this communication, findings from a detailed study aiming to explore potential use of immature flower bud culture in the production of gynogenic $A$. tuncelianum plants were presented. Findings of this study demonstrate that healthy and green $\mathrm{DH}$ A. tuncelianum plants can be developed when sufficient numbers of flower buds are placed in gynogenesis induction media.

\section{Materials And Methods}

Plant Materials

Two accessions of $A$. tuncelianum (AT1 and AT2) were used as donors in the gynogenesis plant production experiment. The bulbs of AT1 and AT2 accessions were collected from the dried plants grown in $2.6 \mathrm{~L}$ black plastic pots filled with a mixture of peat and perlite (2:1) in late July. Bulbs were placed in paper bags and stored in the cold room set at $5^{\circ} \mathrm{C}$ and dark until late-fall. In December, $A$. tuncelianum bulbs were re-planted in $2.6 \mathrm{~L}$ pots and placed in an unheated greenhouse. Bulbs re-sprouted within several weeks after re-planting and produced leaves and pseudo-stems. They began to form flower scapes in mid-spring (Fig. 1A). Flower umbels were collected between May 15 and June 15 with $20 \mathrm{~cm}$ scape. They were brought to the lab, where the bottom portion of scapes were dipped into sterile water in jars, and kept under room conditions until use (Fig 1B).

\section{Preparation of unopened flower bud explants}


The membrane covering the umbel was opened and all open flowers were removed from the umbel manually. Unopened flower buds $(1-2 \mathrm{~mm})$ were cut with a pair of scissors and collected in tea strainer filters (Fig. 1C). Flower buds in tea strainer filters were dipped in $70 \%$ ethanol for $30 \mathrm{~s}$, sterilized in sterilization solution ( $1.05 \%$ sodium hypochlorite with $0.1 \%$ Tween-20) for $30 \mathrm{~min}$ and rinsed three times with sterile distilled water. Surface sterilized buds were spread over sterile papers for $\sim 20 \mathrm{~min}$ to eliminate access water. All activities of unopened flower bud preparation were carried out under sterile conditions in a laminar flow hood.

\section{Establishment of flower bud cultures}

Six BDS- (Dunstan and Short 1977) and nine MS- (Murashige and Skoog 1962) based media were used to test gynogenic plant production potential in A. tuncelianum (Table 1\&2). About 20000 unopened flower buds collected from two different accessions were used (Table 3). Flower buds were placed in 90x15 mm Petri plates containing $\sim 25 \mathrm{ml}$ of induction medium (30 buds/plate). Culture plates were sealed with Parafilm and cultured at $22^{\circ} \mathrm{C}$ under cool white fluorescent and Gro-Lux lights $\left(25-40 \mathrm{Imol} \mathrm{m}^{-2} \mathrm{~s}^{-1}\right)$ with $16 \mathrm{~h}$ light: 8 $\mathrm{h}$ dark photoperiod. Flower buds with gynogenic or somatic response were transferred to Petri plates containing growth medium (GM) composed of half-strength BDS medium supplemented with $30 \mathrm{~g} \mathrm{l}^{-1}$ sucrose and grown under the conditions described above (Fig. D, E.). Plantlets were transferred to $15 \mathrm{~cm}$ glass tubes containing $15 \mathrm{ml}$ of GM and maintained under the conditions described above (Fig.1F, G).

Determination of ploidy levels of $A$. tuncelianum donor and tissue culture -derived materials

Ploidy levels of 10 flower bud donor plants, 17 gynogenic and 10 somatic regenerants were determined following flow cytometry (FCM) analysis protocol reported by Alan et al. (2016) with slight modifications. Four week-old barley (Hordeum vulgare cv. scarpia) seedlings were used as the internal reference standard. Nuclei samples were prepared by chopping fresh A. tuncelianum $(\sim 50 \mathrm{mg})$ and barley $(\sim 5 \mathrm{mg})$ leaf tissues together in $1.5 \mathrm{ml}$ of ice-cold nuclei isolation buffer. Each sample was stained with $5 \mathrm{ml}$ of propidium iodide, which was prepared as $1 \mathrm{mg} / \mathrm{ml}$ stock. Nuclei samples were analyzed with a Cell Lab Quanta SC flow cytometer (Beckman-Coulter). Ploidy levels of $A$. tuncelianum materials were assigned based on the DNA content of their nuclei in relation to the standards. The nuclear DNA content of all $A$. tuncelianum materials were calculated according to formula adapted from Dolezel and Bartos (2005):

A. tuncelianum $2 \mathrm{C}$ nuclear DNA $(\mathrm{pg})=($ A. tuncelianum $2 \mathrm{C}$ peak mean/barley $2 \mathrm{C}$ peak mean $) \times 2 \mathrm{C}$ barley nuclear DNA (pg)

The percentages of $2 \mathrm{C}$ and $4 \mathrm{C}$ nuclei were measured to detect mixoploidy and polyploidy variations in the analyzed samples. The $1 \mathrm{C}$ genome size of $A$. tuncelianum was obtained by converting $\mathrm{pg}$ to $\mathrm{Mbp}$ according to the factor $1 \mathrm{pg}=978 \mathrm{Mbp}$ (Dolezel et al. 2003).

Data Analysis

Responses of two donor $A$. tuncelianum lines to gynogenesis induction were tested, with each Petri plate with the same medium composition and the same genotype considered as a replication. Differences of 
production of gynogenic plantlets and production of gynogenic plants of responsive flower buds were submitted to ANOVA analysis with the data analyzed as a proportion of regeneration in each experimental unit. Differences among groups were tested by the Tukey method $(P>0.05)$ using the MINITAB Statistical Package program. Pseudo-stem diameter and pseudo-stem length differences among gynogenic and somatic plants were also tested with Tukey $(P>0.05)$.

\section{Results}

\section{Responses of $\boldsymbol{A}$. tuncelianum flower buds to culture media}

Flower buds collected from AT1 and AT2 showed similar responses to culture media. Majority of the buds started to open a few days after culture in sucrose containing (50 or $100 \mathrm{~g} / \mathrm{L}$ ) BDS- and MS-based media ( $\mathrm{T} 2, \mathrm{~T} 3, \mathrm{~T} 5, \mathrm{~T} 6, \mathrm{~T} 8, \mathrm{~T} 9, \mathrm{~T} 11, \mathrm{~T} 12, \mathrm{~T} 14, \mathrm{~T} 15)$, whereas those placed in sucrose-free media (T1, T4, T7, T10, T13) started turning to brownish color and did not show any progress throughout entire culture period. Flowers cultured in the media with sucrose grew several times lager in size. Approximately three months after culture initiation, the gynogenic plantlets began to emerge from inside of the flower buds cultured in the media containing sucrose with or without any PGRs. Although analysis of the data obtained did not show statistical significance, there were substantial differences among the responses of $A$. tuncelianum flower buds to induction media. No gynogenesis response was observed in the flower buds cultured in sucrose-free media regardless of presence or absence of PGRs.

Responses of flower buds of different donor genotypes showed slight differences in different culture media. A total of eight $(0.08 \%)$ gynogenic plantlets were obtained from the buds of AT1. The highest gynogenic response $(0.34 \%$ ) of AT1 flower buds was obtained from T12 (MS-based medium containing $1 \mathrm{mg} / \mathrm{I} \mathrm{NAA}, 8$ $\mathrm{mg} / \mathrm{l} 2 \mathrm{IP}$ and $50 \mathrm{~g} / \mathrm{l}$ sucrose). Flower buds of AT1 also showed gynogenic responses in T3 (0.07\%), T6 $(0.08 \%)$, and T9 $(0.14 \%)$. Nine $(0.09 \%)$ gynogenic plantlets were obtained from the flower buds of AT2. Culturing flower buds of AT2 in T2 (PGR- free BDS-based medium with $50 \mathrm{~g} / \mathrm{l}$ sucrose) provided four ( $0.44 \%)$ gynogenic plantlets, the highest gynogenesis response obtained in this study. Flower buds of AT2 genotype also showed response in T3 (0.06\%), T6 (0.26\%), and T15 (0.10\%).

Five of gynogenic plantlets obtained from AT1 donor and three of gynogenic plantlets of AT2 donor origin continued to grow and become plants (Fig. 2A-C). These continued to grow in the culture tubes and did not show any morphological abnormalities. Seven gynogenic plantlets, on the other hand, showed developmental abnormalities (Fig 3 3A-D). Two of these abnormal plants formed bulb-like structures with roots. One was as a stunted albino. There were two stunted gynogenic plantlets with abnormal root formation and remaining two developed callus tissues.

Somatic shoots were induced from the bottom parts of the flower buds of AT1 and AT2 in BDS- and MSbased media containing sucrose and PGRs. Over all frequencies of flower buds with somatic regeneration were similar in both genotypes. Culturing flower buds of AT1 in T5 (BDS-based medium containing $2 \mathrm{mg} / \mathrm{l}$ 2,4D, $2 \mathrm{mg} / \mathrm{l} \mathrm{BAP}$ and $50 \mathrm{~g} / \mathrm{l}$ sucrose) resulted in the development of shoots in $4.44 \%$ of them. The same medium provided somatic shoot formation in $3.89 \%$ of flower buds of AT2 cultured in the same medium. A single somatic shoot from each flower bud was separated and placed in culture tube with EM. Majority of 
the somatic shoots transferred to culture tubes did not respond well to this treatment. A small fraction of these shoots continued to grow and developed to plants.

Determination of ploidy levels of the gynogenic $A$. tuncelianum regenerants

FCM analysis of nuclei samples prepared from greenhouse grown plants of the donor lines showed that the nuclear DNA content of diploid $A$. tuncelianum $(2 n=2 x=16)$ was $26.54 \pm 2.17 \mathrm{pg} / 2 \mathrm{C}$ DNA $\left(\sim 1.30 \times 10^{4}\right.$ $\mathrm{Mbp} / 1 \mathrm{C})$. Nuclear DNA amounts of AT1 and AT2 plants were identical to each other. Analyses of gynogenic plants revealed that two (25\%) of the eight gynogenic plants had 13 pg/2C DNA, which is almost half of the nuclear DNA amount determined for donor plants. Therefore, these two plants were classified as haploid $(1 n=1 x=8)$. Cells of four $(50 \%)$ of the gynogenic plants contained $25.81 \pm 1.56 \mathrm{pg} / 2 \mathrm{C}$ DNA and were classified as diploid. The other two gynogenic plants contained equal amounts of haploid and diploid cells and classified as mixoploid. Gynogenic plantlets with abnormal development were all diploid $(26.81 \pm 2.23$ $\mathrm{pg} / 2 \mathrm{C}$ DNA) (Fig 3). All the somatic shoots developed from the bases of cultured flower buds had nuclear DNA amounts similar to those obtained from the donor plants.

\section{Discussion}

Healthy haploid and diploid plants of A. tuncelianum were obtained for the first time by culturing whole unopened flower buds. Two $A$. tuncelianum genotypes used in the induction experiments showed to response to gynogenesis. Presence of sucrose (50-100 g/l) in the induction media was essential for successful production of gynogenic plantlets. Addition of auxin- and cytokinin-type PGRs into induction media provided gynogenic and somatic plantlet regeneration. Therefore, some of the gynogenesis induction media can also be used in in vitro clonal propagation of $A$. tuncelianum genotypes. It should be also noted that $A$. tuncelianum genotypes showed substantial differences in their responses to gynogenesis induction media. Flower buds of AT2 genotype showed the highest (0.44\%) frequency of gynogenesis response in T2 medium (PGR-free BDS-based medium with $50 \mathrm{~g} / \mathrm{l}$ sucrose). Culturing flower buds of AT1 genotype in T12 (MS-based medium with $1 \mathrm{mg} / \mathrm{NAA}, 8 \mathrm{mg} / \mathrm{l}$ 2IP and $100 \mathrm{~g} / \mathrm{l}$ sucrose) provided the highest $(0.34 \%)$ gynogenesis response. A similar findings were reported by Alan et al. (2016) in the study testing gynogenesis potential of four leek (A. ampeloprasum) genotypes in different induction media. In onion, use of a single induction medium (BDS containing $2 \mathrm{mg} / \mathrm{l}$ 2, 4-D, $2 \mathrm{mg} / \mathrm{l} \mathrm{BAP}$ and $100 \mathrm{~g} / \mathrm{l}$ sucrose) is common procedure in the process of gynogenic plant production (Alan 2021).

FCM analysis showed that there were haploid, mixoploid, and diploid plants among well- developed gynogenic plants. All gynogenic plantlets with abnormal development were diploid. Therefore, abnormal development phenotypes were not related to ploidy levels but likely due to homozygosity of lethal alleles. FCM-based genome size determination via FCM analysis showed that the somatic cells $A$. tuncelianum contains $26.54 \mathrm{pg} / 2 \mathrm{C}$ DNA $\left(\sim 1.30 \times 10^{4} \mathrm{Mbp} / 1 \mathrm{C}\right)$, which is about $6 \mathrm{pg}$ smaller than the genome size of bulb

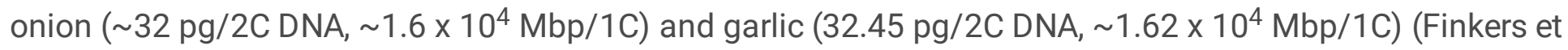
al. 2021, Sun et al. 2020). DH lines are great value to classical and modern genetics studies. Researchers suggested creation of immortal mapping populations to be used as tools for breeders working with complex traits (Walley et al. 2012). Homozygous nature of DH plants makes them ideal for whole-genome 
sequencing projects. Finkers et al. (2021) used a DH line in the study reporting the first de novo assembly of the genome sequence of onion. Another group of researchers suggested use of DH onion line as reference for bulb Onion research (ekle).

$\mathrm{DH}$ lines are fully homozygous lines that can be used in place of conventional inbred lines in breeding programs. Therefore, there is a great deal of interest in developing $\mathrm{DH}$ lines for use in plant breeding programs. The major limitations before the utilization of $\mathrm{DH}$ technique in Allium improvement programs are low frequencies of haploid plant production, high losses during chromosome doubling, and difficulties faced during selfed seed production. Prior to the study published by Alan et al. (2016) leek was considered as recalcitrant to gynogenesis induction. An efficient gynogenesis production protocol is, now, available for leek and allows production of dihaploid plants from all genotypes of this tetraploid Allium species (Celebi-Toprak and Alan 2021). Onion can be considered as model for DH application in Allium breeding programs (Alan 2021). Gynogenesis-based DH technique allows production of DH onion plants in one year. Production of selfed seeds from DH onion takes another year. DH lines developed from long day-type OP onion lines were shown to be excellent male parents in F1 hybrid production (Hyde et al. 2012). A. tuncelianum is a diploid species like onion. With further improvement of gynogenesis-based $\mathrm{DH}$ technique, production of fecund $\mathrm{DH}$ A. tuncelianum plants may be possible in two years. Even though overall gynogenesis response frequency obtained in $A$. tuncelianum is substantially lower than onion and leek, researchers can produce gynogenic plants by placing higher numbers of flower buds in induction media. Chromosome doubling procedure developed for onion can be used to convert haploid plants to fecund DHs.

A. tuncelianum produces perfect fertile flowers allowing seed production via selfing or out crossing. Its ability to produce true seeds may allow genetic improvement of this species via classical and modern breeding techniques. Genetic improvement of $A$. tuncelianum would require application of a combination of classical and modern breeding techniques. The first step in that direction would be development of biennial lines producing single large bulbs from direct seed planting in the first growth season and produce seeds in the second season. These lines can be used in the production of genetically uniform lines via gynogenesisbased doubled haploid (DH) technology. In the second step, DH lines developed can be grown to form bulbs and selfed seeds and evaluated for the traits of interest. DH lines with desirable traits can be used new varieties or used as parents in the development of F1 hybrid varieties.

\section{Declarations}

\section{Funding}

This work was funded by the Pamukkale University, Plant Genetics and Biotechnology Aplication and Research Center (PAÜ BIYOM).

\section{Conflicts of interest}

Fevziye Celebi-Toprak, Zeynep Ergun and Ali R. Alan declare that they have no conflict of interest.

\section{Ethics approval and consent to participate}


Not applicable.

\section{Consent for publication}

Not applicable.

\section{Availability of data and materials}

All data generated or analyzed during this study are included in this published article.

\section{Authors' contributions}

All authors contributed to the study conception and design. Material preparation, data collection and analysis were performed by Fevziye Çelebi-Toprak, Zeynep Ergun and Ali R. Alan. The first draft of the manuscript was written by Ali R. Alan. Fevziye Çelebi-Toprak, Zeynep Ergun and Ali R. Alan edited the manuscript. All authors approved the final manuscript.

\section{References}

Alan AR (2021) Doubled haploid onion (Allium cepa L.) production via in vitro gynogenesis. In: SeguiSimarro JM (eds) Doubled haploid technology. Methods in molecular biology, Humana, New York, NY, pp 151-169

Alan AR, Mutschler MA, Brants A, Cobb E, Earle ED (2003) Production of gynogenic plants from hybrids of Allium cepa L. and A. roylei Stearn. Plant Science 165:1201-1211

Alan AR, Brants A, Cobb E, Goldschmied PA, Mutschler MA, Earle ED (2004) Fecund gynogenic lines from onion (Allium cepa L.) breeding materials. Plant Science 167:1055-1066

Alan AR, Celebi-Toprak F, Kaka A (2016) Production and evaluation of gynogenic leek (Allium ampeloprasum L.) plants. Plant Cell Tissue Organ Culture 125:249-259

Bohanec B and Jakse M (1999) Variations in gynogenic response among long-day onion (Allium cepa L.) accessions. Plant Cell Reports 18:737-742

Campion B and Alloni C (1990) Induction of haploid plants in onion (Allium cepa L.) by in vitro culture of unpollinated ovules. Plant Cell Tissue Org Cult 20:1- 6

Celebi-Toprak F; Alan AR (2021) In vitro gynogenesis in leek (Allium ampeloprasum L.). In: Segui-Simarro JM (eds) Doubled haploid technology. methods in molecular biology, Humana, New York, NY, pp: 171-184

Dolezel J; Bartos J (2005) Plant DNA flow cytometry and estimation of genome size. Ann Bot 95:99-110

Dolezel J; Bartos J; Voglmayr H; Greilhuber J (2003) Nuclear DNA content and genome size of trout and human. Cytometry 51:127-128 
Dunstan DI and Short KC (1977) Improved growth of tissue cultures of onion, Allium cepa. Phsiologia Plantarum 41:70-72

Dunwell JM (2010) Haploids in flowering plants: origins and exploitation. Plant Biotechnol J 8:377-424

Etoh T, Simon PW (2002) Diversity, fertility and seed production of garlic. In: Rabinowitch HD, Currah L (eds) Allium Crop Science: Recent Advances,. CABI Publishing, New York, pp 101-117

Finkers R; Kaauwen M; Ament K; Burger-Meijer K; Egging R; Huits H; Kodde L; Kroon L; Shigyo M; Sato S; Vosman B; van Workum W; Scholten $O$ (2021) Insights from the first genome assembly of onion (Allium cepa), G3 Genes Genoms Genetics. doi:10.1093/g3journal/jkab243

Hyde PT; Earle ED; Mutschler MA (2012) Doubled haploid onion ( Allium cepa L.) lines and their impact on hybrid performance. Hortscience 47(12): 1690-1695

Ipek M, Ipek A, Simon PW (2008) Genetic characterization of Allium tuncelianum: an endemic edible Allium species with garlic odor. Sci Hortic 115:409-415

Kaska A, Celebi-Toprak F, Alan AR (2020a) Induction of somatic and gynogenic regeneration in Tunceli garlic (Allium tuncelianum). Acta Hortic 1285:231-234. doi: 10.17660/ActaHortic.2020.1285.34

Kaska A, Celebi-Toprak F, Alan AR (2020b) Genetically pure Turkish onion (Allium cepa L.) lines. Acta Hortic 1285:203-212. doi: 10.17660/ActaHortic.2020.1285.31

Keller J (1990) Culture of unpollinated ovules, ovaries, and flower buds in some species of the genus Allium and haploid induction via gynogenesis in onion (Allium cepa L.), Euphytica 47:241-24

Keller J, Korzun L (1996) Haploidy in onion (Allium cepa L.) and other Allium species. In: Jain MS, Sopory SK, Veilleux RE (eds) In vitro haploid production in higher plants, vol 3. Kluwer Academic Publishers, Dordrecht, pp 51-75

Kizil S, Khawar KM (2017) Introduction of endemic Allium tuncelianum Kollman from hot and temperate climate to semi-arid climatic conditions. Acta Sci. Pol. Hortorum Cultus, 16(5): 117-124

Kizil S, Tekin F, Khawar KM, Saglam S, Ertekin AS, Arslan N (2012) An investigation about economically important bulbous plants found in Southeastern and East Anatolia Regions of Turkey. XI. International Flower Bulbs and Herbaceous Perennials (ISHS), Antalya, Turkey.

Kojima A, Kawaguchi T (1989) Apomictic nature of Chinese chive (Allium tuberosum rottl.) detected in unpollinated ovule culture. Japanese Journal of Breeding 39(4): 449-456

Murashige T and Skoog F (1962) A revised medium for rapid growth and bioassay with tobacco cell culture. Plant Physiology 15:473-497

Muren RC (1989) Haploid plant induction from unpollinated ovaries in onion. HortScience 24:833-834 
Özhatay N (2002) Diversity of bulbous monocots in Turkey with special reference. Chromosome numbers. Pure Appl Chem 74(4):547-555. https://doi.org/10.1351/pac200274040547.

Sulistyaningsih E, Yamashita K, Tashiro Y (2002) Haploid induction from F1 hybrids between CMS shallot with Allium galanthum cytoplasm and common onion by unpollinated flower culture. Euphytica 125, 139.doi: 10.1023/A:1015756729401

Sun X, Zhu S, Li N, Cheng Y, Zhao J, Qiao X, Lu L, Liu S, Wang Y, Liu, C, Li B, Guo W, Gao S, Yang Z, Li F, Zeng Z, Tang Q, Pan Y, Guan M, Zhao J, Lu X, Meng H, Han Z, Gao C, Jiang W, Zhao X, Tian S, Su J, Cheng Z, Liu T (2020) A chromosome-level genome assembly of garlic (Allium sativum) provides insights into genome evolution and allicin biosynthesis. Mol Plant. 13: 1328-1339

Walley PG, Carder J, Skipper E, Mathas E, Lynn J, Pink D, Buchanan-Wollaston V (2012) A new broccoli x broccoli immortal mapping population and framework genetic map: tools for breeders and complex trait analysis. Theor Appl Genet. 124(3):467-84. doi: 10.1007/s00122-011-1721-6.

\section{Tables}

Table 1. Composition of BDS-based culture media 
BDS-based media

\begin{tabular}{lllllll}
\hline Composition & T1 & T2 & T3 & T4 & T5 & T6 \\
\hline Macro and micro elements & & & & & & \\
\hline BDS macro \& micro elements & & + & + & + & + & + \\
\hline Iron source (mg/l) & & & & & & \\
\hline FeNaEDTA & 37.25 & 37.25 & 37.25 & 37.25 & 37.25 & 37.25 \\
\hline Vitamins. amino acids and other organic supplements (mg/l) & & & \\
\hline Myo-inositol & 500 & 500 & 500 & 500 & 500 & 500 \\
\hline Thiamine-HCl & 10 & 10 & 10 & 10 & 10 & 10 \\
\hline Pyridoxine HCl & 1 & 1 & 1 & 1 & 1 & 1 \\
\hline Nicotinic acid & 1 & 1 & 1 & 1 & 1 & 1 \\
\hline L-proline & 200 & 200 & 200 & 200 & 200 & 200 \\
\hline Growth regulators (mg/l) & & & & & & \\
\hline 2,4-Dichlorophenoxyacetic acid (2,4 D) & - & - & - & 2 & 2 & 2 \\
\hline 6-Benzylaminopurine (BAP)) & - & - & - & 2 & 2 & 2 \\
\hline Carbohydrate and gelling agent (g/l) & & & & & & \\
\hline Sucrose & 0 & 50 & 100 & 0 & 50 & 100 \\
\hline Agar & 7.4 & 7.4 & 7.4 & 7.4 & 7.4 & 7.4 \\
\hline pH & 6 & 6 & 6 & 6 & 6 & 6 \\
\hline
\end{tabular}

a Dunstan and Short (1977)

Table 2. Composition of MS-based culture media 
MS-based media

$\begin{array}{llllllllll}\text { Composition } & \text { T7 } & \text { T8 } & \text { T9 } & \text { T10 } & \text { T11 } & \text { T12 } & \text { T13 } & \text { T14 } & \text { T15 }\end{array}$

Macro and micro

elements

MS macro \& micro

elements $^{a}$

Iron source $(\mathrm{mg} / \mathrm{l})$

FeNaEDTA

$37.25 \quad 37.25$

37.25

37.25

37.25

37.25

$37.25 \quad 37.25$

37.25

Vitamins. amino acids and other organic supplements ( $\mathrm{mg} / \mathrm{l})$

\begin{tabular}{llllllllll} 
Myo-inositol & 500 & 500 & 500 & 500 & 500 & 500 & 500 & 500 & 500 \\
\hline Thiamine-HCl & 10 & 10 & 10 & 10 & 10 & 10 & 10 & 10 & 10 \\
\hline Pyridoxine $\mathrm{HCl}$ & 0.5 & 0.5 & 0.5 & 0.5 & 0.5 & 0.5 & 0.5 & 0.5 & 0.5 \\
\hline Nicotinic acid & 0.5 & 0.5 & 0.5 & 0.5 & 0.5 & 0.5 & 0.5 & 0.5 & 0.5 \\
\hline Glycine & 2 & 2 & 2 & 2 & 2 & 2 & 2 & 2 & 2
\end{tabular}

Growth regulators

$(m g / l)$

2,4-

Dichlorophenoxyacetic

acid $(2,4 \mathrm{D})$

6-Benzylaminopurine (BAP)

a-naphthaleneacetic

acid (NAA)

Isopentenyl adenine

$(2 \mathrm{IP})$

Carbohydrate and gelling agent $(\mathrm{g} / \mathrm{l})$

\begin{tabular}{llllllllll} 
Sucrose & 0 & 50 & 100 & 0 & 50 & 100 & 0 & 50 & 100 \\
\hline Agar & 7.9 & 7.9 & 7.9 & 7.9 & 7.9 & 7.9 & 7.9 & 7.9 & 7.9 \\
$\mathrm{pH}$ & 6 & 6 & 6 & 6 & 6 & 6 & 6 & 6 & 6
\end{tabular}

${ }^{a}$ Murashige and Skoog (1962)

Table 3. In vitro cultures established with the flower buds of AT1 and AT2 donors 


\begin{tabular}{|cll|}
\hline \multicolumn{3}{|c|}{ AT1 } \\
& Flower buds cultured & Flower buds cultured \\
\hline Media & & \\
\hline T1 & 330 & 600 \\
\hline T2 & 420 & 900 \\
\hline T3 & 1404 & 1680 \\
\hline T4 & 330 & 660 \\
\hline T5 & 180 & 900 \\
\hline T6 & 2610 & 780 \\
\hline T7 & 540 & 720 \\
\hline T8 & 390 & 210 \\
\hline T9 & 720 & 420 \\
\hline T10 & 240 & 240 \\
\hline T11 & 570 & 240 \\
\hline T12 & 1170 & 360 \\
\hline T13 & 180 & 720 \\
\hline T14 & 210 & 300 \\
\hline T15 & 690 & 1050 \\
\hline 15 & 9984 & 9780 \\
\hline Total & & \\
\hline & & \\
\hline
\end{tabular}

Table 4. Gynogenesis responses of $A$. tuncelianum genotypes 


\begin{tabular}{|c|c|c|c|c|c|}
\hline $\begin{array}{l}\text { Donor } \\
\text { genotypes }\end{array}$ & Media & $\begin{array}{l}\text { Responsive } \\
\text { buds (\%) }\end{array}$ & Gynogenic plantlets (\%) & Gynogenic plants (\%) & $\begin{array}{l}\text { Plantlet/plant } \\
\text { ratio }\end{array}$ \\
\hline \multirow[t]{15}{*}{ AT1 } & T1 & $0 \mathrm{~A}$ & $0 \mathrm{~A}$ & $0 \mathrm{~A}$ & 0 \\
\hline & T2 & $0 \mathrm{~A}$ & $0 \mathrm{~A}$ & $0 \mathrm{~A}$ & 0 \\
\hline & T3 & $1(0.07) \mathrm{A}$ & $1(0.07) \mathrm{A}$ & $1(0.07) \mathrm{A}$ & 100 \\
\hline & T4 & $0 \mathrm{~A}$ & $0 \mathrm{~A}$ & $0 \mathrm{~A}$ & 0 \\
\hline & T5 & $0 \mathrm{~A}$ & $0 \mathrm{~A}$ & $0 \mathrm{~A}$ & 0 \\
\hline & T6 & $2(0.08) A$ & $2(0.08) A$ & $0 \mathrm{~A}$ & 0 \\
\hline & T7 & $0 \mathrm{~A}$ & $0 \mathrm{~A}$ & $0 \mathrm{~A}$ & 0 \\
\hline & T8 & $0 \mathrm{~A}$ & $0 \mathrm{~A}$ & $0 \mathrm{~A}$ & 0 \\
\hline & T9 & $1(0.14) \mathrm{A}$ & $1(0.14) \mathrm{A}$ & $1(0.14) \mathrm{A}$ & 100 \\
\hline & T10 & $0(\mathrm{~A})$ & $0(A)$ & $0(\mathrm{~A})$ & 0 \\
\hline & T11 & $0 \mathrm{~A}$ & $0 \mathrm{~A}$ & $0 \mathrm{~A}$ & 0 \\
\hline & T12 & $4(0.34) A$ & $4(0.34) A$ & $3(0.26) \mathrm{A}$ & 75 \\
\hline & T13 & $0 \mathrm{~A}$ & $0 \mathrm{~A}$ & $0 \mathrm{~A}$ & 0 \\
\hline & T14 & $0 \mathrm{~A}$ & $0 \mathrm{~A}$ & $0 \mathrm{~A}$ & 0 \\
\hline & T15 & $0 \mathrm{~A}$ & $0 \mathrm{~A}$ & $0 \mathrm{~A}$ & 0 \\
\hline Total & 15 & $8(0.08)$ & $8(0.08)$ & $5(0.05)$ & 62.50 \\
\hline \multirow[t]{12}{*}{ AT2 } & T1 & $0 \mathrm{~A}$ & $0 \mathrm{~A}$ & $0 \mathrm{~A}$ & 0 \\
\hline & $\mathrm{T} 2$ & $4(0.44) \mathrm{A}$ & $4(0.44) \mathrm{A}$ & $2(0.22) A$ & 50 \\
\hline & T3 & $1(0.06) \mathrm{A}$ & $1(0.06) \mathrm{A}$ & $0 \mathrm{~A}$ & 0 \\
\hline & T4 & $0 \mathrm{~A}$ & $0 \mathrm{~A}$ & $0 \mathrm{~A}$ & 0 \\
\hline & T5 & $0 \mathrm{~A}$ & $0 \mathrm{~A}$ & $0 \mathrm{~A}$ & 0 \\
\hline & T6 & $2(0.26) A$ & $2(0.26) A$ & $0 \mathrm{~A}$ & 0 \\
\hline & T7 & $0 \mathrm{~A}$ & $0 \mathrm{~A}$ & $0 \mathrm{~A}$ & 0 \\
\hline & T8 & $0 \mathrm{~A}$ & $0 \mathrm{~A}$ & $0 \mathrm{~A}$ & 0 \\
\hline & T9 & $0 \mathrm{~A}$ & $0 \mathrm{~A}$ & $0 \mathrm{~A}$ & 0 \\
\hline & T10 & $0 \mathrm{~A}$ & $O A$ & $O A$ & 0 \\
\hline & T11 & $0 \mathrm{~A}$ & $0 \mathrm{~A}$ & $0 \mathrm{~A}$ & 0 \\
\hline & T12 & $1(0,28) \mathrm{A}$ & $1(0.28) \mathrm{A}$ & $1(0.28) \mathrm{A}$ & 100 \\
\hline
\end{tabular}




\begin{tabular}{|llllll|} 
& T13 & 0 A & O A & $0 \mathrm{~A}$ & 0 \\
\hline & T14 & 0 A & 0 A & O A & 0 \\
\hline Total & T15 & $1(0.10) \mathrm{A}$ & $1(0.10) \mathrm{A}$ & $0 \mathrm{~A}$ & 0 \\
\hline
\end{tabular}

a Values with the same letter are not significantly different from each other (Tukey, $P>0,05$.)

Table 5 Somatic plant regeneration 


\begin{tabular}{|c|c|c|c|c|c|}
\hline $\begin{array}{l}\text { Donor } \\
\text { genotypes }\end{array}$ & Media & $\begin{array}{l}\text { Responsive } \\
\text { buds (\%) }\end{array}$ & $\begin{array}{l}\text { Somatic plantlets } \\
(\%)\end{array}$ & $\begin{array}{l}\text { Somatic plants } \\
(\%)\end{array}$ & $\begin{array}{l}\text { Plantlet/plant } \\
\text { ratio }\end{array}$ \\
\hline \multirow[t]{15}{*}{ AT1 } & T1 & $0 \mathrm{~A}$ & $0 \mathrm{~A}$ & $0 \mathrm{~A}$ & 0 \\
\hline & T2 & $0 \mathrm{~A}$ & $0 \mathrm{~A}$ & $0 \mathrm{~A}$ & 0 \\
\hline & T3 & $0 \mathrm{~A}$ & $0 \mathrm{~A}$ & $0 \mathrm{~A}$ & 0 \\
\hline & T4 & $0 \mathrm{~A}$ & $0 \mathrm{~A}$ & $0 \mathrm{~A}$ & 0 \\
\hline & T5 & $8(4.44) \mathrm{A}$ & $8(4.44) \mathrm{A}$ & $1(0.56) \mathrm{A}$ & 12.50 \\
\hline & T6 & 87 (3.33) A & 87 (3.33) A & $11(0.42) \mathrm{A}$ & 12.64 \\
\hline & T7 & $0 \mathrm{~A}$ & $0 \mathrm{~A}$ & $0 \mathrm{~A}$ & 0 \\
\hline & T8 & $0 \mathrm{~A}$ & $0 \mathrm{~A}$ & $0 \mathrm{~A}$ & 0 \\
\hline & T9 & $0 \mathrm{~A}$ & $0 \mathrm{~A}$ & $0 \mathrm{~A}$ & 0 \\
\hline & T10 & $0 \mathrm{~A}$ & $0 \mathrm{~A}$ & $0 \mathrm{~A}$ & 0 \\
\hline & T11 & $6(1.05) \mathrm{A}$ & $6(1.05) \mathrm{A}$ & $1(0.18) A$ & 16.67 \\
\hline & T12 & 27 (2.31) A & 27 (2.31) A & $5(0.43) \mathrm{A}$ & 18.52 \\
\hline & T13 & $0 \mathrm{~A}$ & $0 \mathrm{~A}$ & $0 \mathrm{~A}$ & 0 \\
\hline & T14 & $1(0,48) A$ & $1(0.48) \mathrm{A}$ & $0 \mathrm{~A}$ & 0 \\
\hline & T15 & $5(0.73) \mathrm{A}$ & $5(0.73) \mathrm{A}$ & $0 \mathrm{~A}$ & 0 \\
\hline Total & 15 & $134(1.34)$ & $134(1.34)$ & $18(0.18)$ & 13.43 \\
\hline \multirow[t]{12}{*}{ AT2 } & T1 & $0 \mathrm{~A}$ & $0 \mathrm{~A}$ & $0 \mathrm{~A}$ & 0 \\
\hline & T2 & $0 \mathrm{~A}$ & $0 \mathrm{~A}$ & $0 \mathrm{~A}$ & 0 \\
\hline & T3 & $0 \mathrm{~A}$ & $0 \mathrm{~A}$ & $0 \mathrm{~A}$ & 0 \\
\hline & T4 & $0 \mathrm{~A}$ & $0 \mathrm{~A}$ & $0 \mathrm{~A}$ & 0 \\
\hline & T5 & 35 (3.89) A & 35 (3.89) A & $6(0.67) A$ & 17.14 \\
\hline & T6 & $19(2.44) \mathrm{A}$ & $19(2.44) \mathrm{A}$ & $2(0.26) \mathrm{A}$ & 10.53 \\
\hline & T7 & $0 \mathrm{~A}$ & $0 \mathrm{~A}$ & $0 \mathrm{~A}$ & 0 \\
\hline & T8 & $0 \mathrm{~A}$ & $0 \mathrm{~A}$ & $0 \mathrm{~A}$ & 0 \\
\hline & T9 & $0 \mathrm{~A}$ & $0 \mathrm{~A}$ & $0 \mathrm{~A}$ & 0 \\
\hline & T10 & $0 \mathrm{~A}$ & $0 \mathrm{~A}$ & $0 \mathrm{~A}$ & 0 \\
\hline & $\mathrm{T} 11$ & $3(1.25) \mathrm{A}$ & $3(1.25) \mathrm{A}$ & $0 \mathrm{~A}$ & 0 \\
\hline & T12 & $8(2,22) A$ & $8(2.22) \mathrm{A}$ & $1(0.28) \mathrm{A}$ & 12.50 \\
\hline
\end{tabular}




\begin{tabular}{|c|c|c|c|c|c|c|}
\hline & T13 & $0 \mathrm{~A}$ & $0 \mathrm{~A}$ & & $0 \mathrm{~A}$ & 0 \\
\hline & T14 & $8(2.67) \mathrm{A}$ & 8 (2.67) A & & $0 \mathrm{~A}$ & 0 \\
\hline & T15 & $26(2.48) A$ & $26(2.48) \mathrm{A}$ & & $6(0.57) A$ & 23.08 \\
\hline Total & 15 & $\begin{array}{l}99 \\
(1.01)\end{array}$ & 99 (1.01) & $15(0.15)$ & & 15.15 \\
\hline
\end{tabular}

* a Values with the same letter are not significantly different from each other (Tukey, $P>0,05)$.

Table 6. Ploidy levels of the gynogenic plants obtained from two A. tuncelianum donor genotypes

\begin{tabular}{lllll}
\multicolumn{5}{l}{ Ploidy level } \\
\hline Donor & Gynogenic plants tested & $\mathrm{n}(\%)$ & $\mathrm{n}+2 \mathrm{n}(\%)$ & $2 \mathrm{n}(\%)$ \\
\hline AT1 & 5 & $1(20)$ & $2(40)$ & $2(40)$ \\
\hline AT2 & 3 & $1(33.33)$ & - & $2(66.66)$ \\
\hline Total & 8 & $2(25)$ & $2(25)$ & $4(50)$
\end{tabular}

Figures 


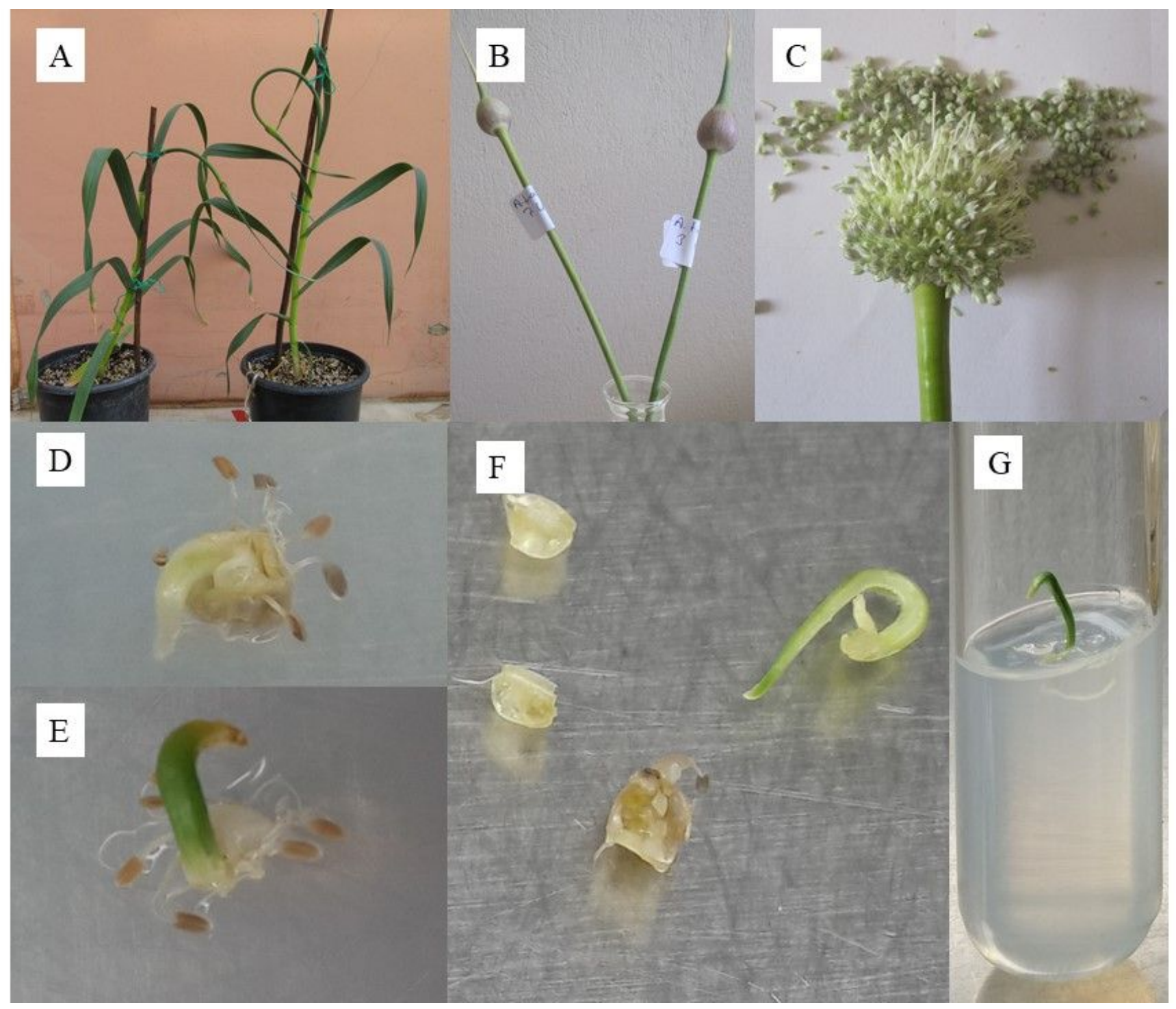

\section{Figure 1}

Gynogenic plant production in A. tuncelianum. a. Donor A. tuncelianum plants grown in the pots. b. Scapes with immature flower buds. c. Excision of immature flower buds from an umbel. d. Emergence of a gynogenic plantlet from a cultured flower bud of AT1 genotype. e. Emergence of a gynogenic plantlet from a cultured flower bud of AT2 genotype. f. A gynogenic plantlet separated from a responsive flower bud. g. A gynogenic plantlet transferred into a culture tube. 


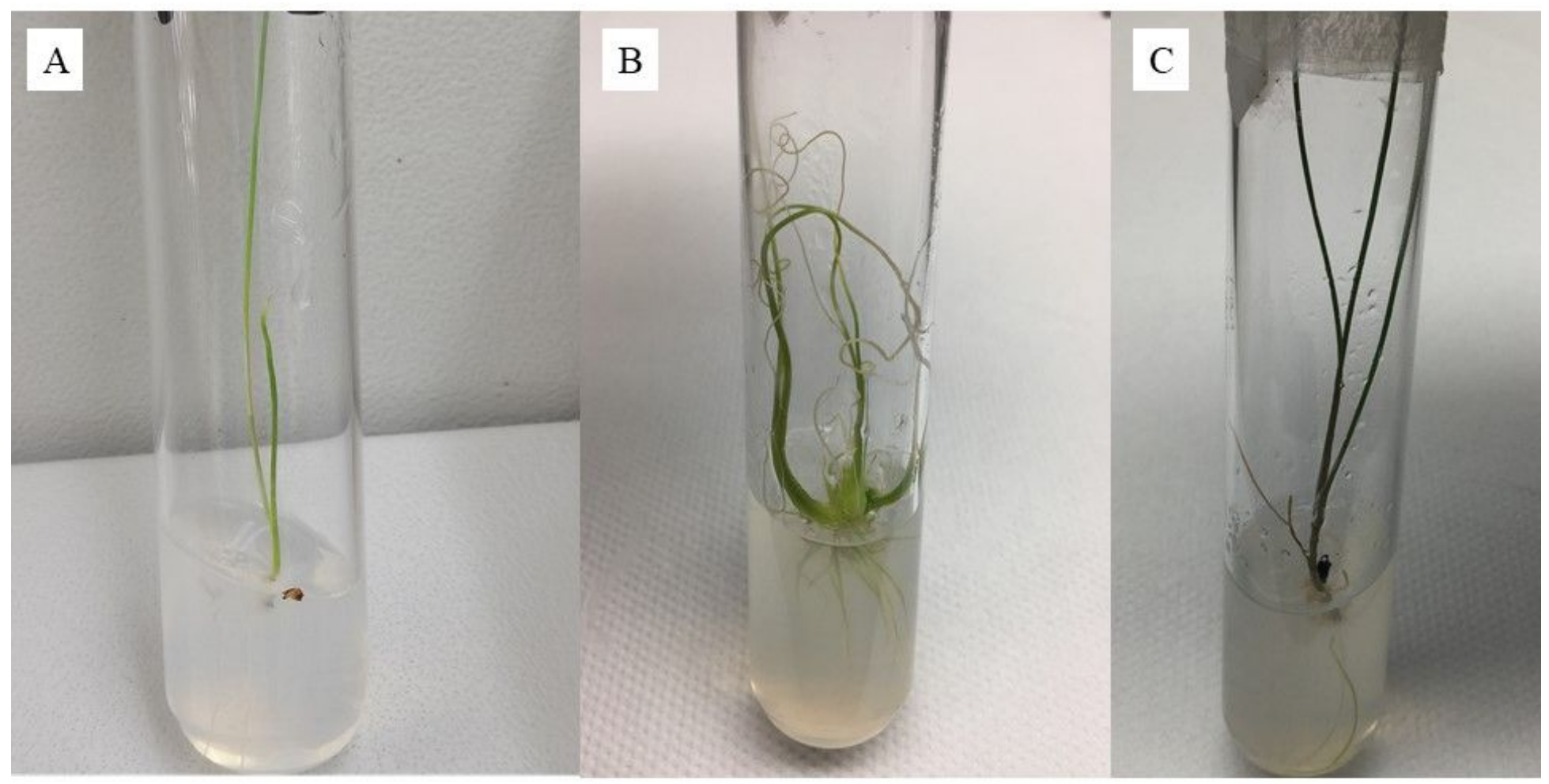

Figure 2

Gynogenic A. tuncelianum plants. a. A haploid gynogenic plant. b. A mixoploid gynogenic plant with haploid and diploid cells. c. A diploid gynogenic plant. 


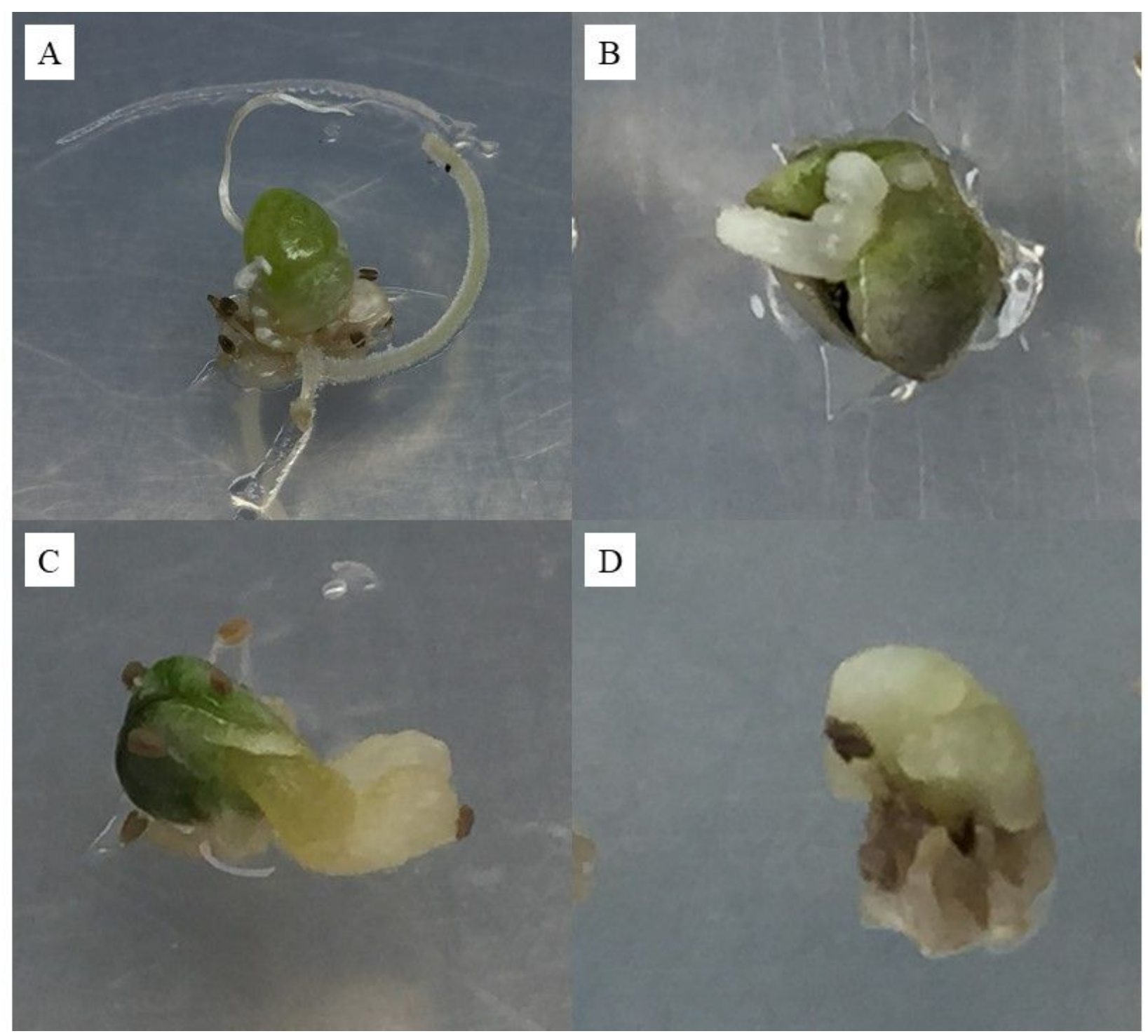

\section{Figure 3}

Gynogenic A. tuncelianum plantlets with developmental abnormalities. a. Plantlet forming a bulb-like structure with roots. b. A stunted albino plantlet. c. A stunted plantlet with enlarged root. d. A plantlet with extensive callus formation. 